\title{
Plant drought survival under climate change and strategies to improve perennial grasses. A review
}

\author{
Mark R. Norton ${ }^{1,2}$ - Dariusz P. Malinowski ${ }^{3}$. Florence Volaire ${ }^{4}$
}

Accepted: 22 March 2016/Published online: 19 April 2016

(C) The Author(s) 2017. This article is published with open access at Springerlink.com

\begin{abstract}
The three cool-season perennial forage grasses cocksfoot/orchardgrass, Dactylis glomerata L., tall fescue, Festuca arundinacea Schreb. syn. Lolium arundinaceum (Schreb.) Darbysh., and phalaris/harding grass, Phalaris aquatica L., are of major economic and ecological importance in regions with summer-dry environments. This review considers the constraints that these species are likely to experience under current and predicted increase of droughts due to climate change scenarios in south-eastern Australia, the southern Great Plains of USA and the Western Mediterranean Basin. The review identifies research required to maximise the development and use of $\mathrm{C} 3$ cool-season grasses with enhanced resilience to drought while considering the concern of some regulators that these grasses may be potential weeds. The state of knowledge of factors influencing plant drought survival and therefore recovery after stress and long-term persistence is discussed in the light of adaptive strategies. The major research needs identified to enhance traits conferring drought survival include (1) increasing the depth and density of grass root systems to strengthen dehydration avoidance; (2) exploring the
\end{abstract}

The original version of this article was revised due to a retrospective Open Access order. The erratum is available under DOI 10.1007/s13593-0170451-9.

Mark R. Norton

mark.norton@dpi.nsw.gov.au

1 NSW DPI, Agricultural Institute, PMB, Wagga Wagga, NSW 2650, Australia

2 Graham Centre for Agricultural Innovation, Locked Bag 588, Wagga Wagga, NSW 2650, Australia

3 Texas AgriLife Research, P.O. Box 1658, Vernon, TX, USA

4 INRA USC 1338, CEFE UMR 5175, CNRS, Université de Montpellier - Université Paul-Valéry Montpellier - EPHE, 1919 Route de Mende, 34293 Montpellier cedex, France biochemical, molecular and hydraulic bases of dehydration tolerance and improving techniques to measure this trait; (3) breaking the trade-off between summer dormancy and forage yield potential and improving understanding of environmental, biochemical and genetic controls over summer dormancy; (4) identifying non-toxic endophyte strains compatible with summer-dormant cultivars of tall fescue to enhance drought survival; and (5) enhancing seed production capability of new cultivars as well as the development of agronomic management packages for promoting stable mixtures combining perennial grasses and legumes. The weed potential of newly introduced summer-dormant cultivars is concluded to be minor. The research directions proposed here should improve pasture grass resilience and forage crop sustainability in Mediterranean and temperate summer-dry environments under the future drier and warmer conditions associated with climate change.

Keywords Summer dormancy · Dehydration tolerance · Dehydration avoidance $\cdot$ Drought survival

\section{Contents}

1. Introduction

1.1 Projected climates and impact on pastures and grasslands

1.1.1 The case of southern Australia

1.1.2 The case of the Mediterranean Basin

1.1.3 The case of the Southern Great Plains of the USA

1.2 The role of $\mathrm{C} 3$ versus $\mathrm{C} 4$ perennial forage grasses

2. Strengthening drought survival strategies of perennial grasses

2.1 Drought escape - the importance of reliable seed production

2.2 Dehydration avoidance/delay and rooting system improvement 
2.3 Dehydration tolerance to improve survival of drought

2.4 Summer dormancy to improve survival of extended, extreme drought

2.5 Drought tolerance - the role of endophytes

3. Regulatory constraints to use of drought tolerant coolseason grasses - putative weed potential

4. Conclusion and future directions

\section{Introduction}

\subsection{Projected climates and impact on pastures and grasslands}

Grasslands cover $70 \%$ of the world's agricultural surface and support crop-livestock farming systems that contribute to the livelihoods of more than 800 million people worldwide (2013). Furthermore, they produce forage for many of the world's grazing animals both in developed and developing nations and provide crucial ecosystem services including carbon sequestration, protection and enrichment of the soil and preservation of biodiversity (Gaujour et al. 2012). However, the stability of both native and sown grasslands and the sustainability of the pastoral agriculture which is dependent on them will be challenged by global climate change (Tubiello et al. 2007). Depending upon the greenhouse gas emission scenario chosen, the projected increases in mean global annual temperature vary by between 2.5 and $4.3{ }^{\circ} \mathrm{C}$ in most cropgrowing regions in the world by 2080 to 2099 (IPCC 2014). Despite the fertilisation effects of increased atmospheric $\mathrm{CO}_{2}$, extreme events including severe heat waves and droughts may become more frequent in a changing climate compounding the level of stress on grassland plants (Schar and Jendritzky 2004; Brookshire and Weaver 2015).

To give these predictions a regional perspective, the projected changes in climate for southern Australia, the Southern Great Plains of the USA and southern Europe will be proposed as examples of the types of challenges that grasslands are predicted to experience in the near future.

\subsubsection{The case of southern Australia}

In southern Australia, severe droughts of great intensity, duration and extent have, since British settlement, been a major constraint to agriculture (Verdon-Kidd and Kiem 2009). As an example, the so-called Millennium Drought, which lasted with varying intensity from approximately 2002 to 2009, has had a strong detrimental effect on southern Australian agriculture (Kirkegaard and Hunt 2010) particularly by increasing the level of farmer debt. However, it has also awakened some farmers to the increased flexibility that grazing animal enterprises when mixed with cropping provide to farm viability, in comparison to enterprises based solely on the cropping of annual species (Nordblom et al. 2015). Associated with these events, there has been renewed interest in ways to improve the persistence of pasture plants under drought, an example in the cool-season pasture scene being the renewed introduction into the market of tall fescues with the summer dormancy trait (Miller 2000). In southern Australia, located between latitudes $30^{\circ}$ and $43^{\circ} \mathrm{S}$, depending on the greenhouse gas emission scenario chosen, the climate is expected to experience between 2 and $8 \%$ more evapotranspiration, temperatures will increase by between 1.5 and $3{ }^{\circ} \mathrm{C}$, and annual rainfall will decline by between 2 and $5 \%$. Moreover, the more northerly part of this region is likely to receive between 2 and $5 \%$ more rainfall in summer than currently (www.climatechangeinaustralia.gov.au). It is likely there will be specific challenges that drier, warming climates will pose to much of the current $\mathrm{C} 3$ grass germplasm we use in these latitudes. For example, in southern Australia, the length of the cool season appears to be shortening including a later start to autumn rains that begin the growth of cool-season species together with an earlier finish to their growing season at the end of spring (Wang et al. 2009).

\subsubsection{The case of the Mediterranean Basin}

In Europe, a decline in summer precipitation, with associated increases in solar radiation and temperature, both enhancing evapotranspiration, will lead to more frequent and more intense droughts (Lehner et al. 2006). Thus, the widespread devastating drought and heat wave observed over Europe in the summer of 2003 (Ciais et al. 2005) might become more usual. Indeed, in the Mediterranean Basin, the rate of warming may lead to an additional month of summer (Giannakopoulos et al. 2009). This increasing water deficit will also worsen in winter since ten of the 12 driest winters since 1902 have occurred in just the last 20 years (Hoerling et al. 2012). Therefore, pasture establishment failures and long-term degradation from drought are expected to become more common (Briske et al. 2003). Around the Mediterranean Basin, mixed crop-livestock farming systems contribute significantly to the rural economy. In southern Europe, livestock farming provides high-added value animal products (typically cheese and meat), but the recent decrease in grazing pressure, brought about by the widespread population shift from rural to urban areas, negatively impacts the landscape since the lack of farmers allows shrub encroachment, thus increasing wildfire frequency. In Northern Africa, animal production is widespread and mostly extensive, often with a strong negative impact because of overgrazing on rangelands. However, greater production of animal products is required to satisfy the need of growing populations (Delgado et al. 1999; FAO 2009). In Morocco for example, public actions ('Plan Vert') have been implemented to foster livestock farming. In all cases, a key determinant for the sustainability of animal production is self- 
sufficiency in on-farm forage supply, to counterbalance the increasing cost of feed stuff sourced off-farm (Abdelguerfi and El Hassani 2011; Taher Sraïri 2011). All around the Mediterranean Basin, rangelands and grasslands cover over $50 \%$ of the land surface and about 270 million ha in the arid and semi-arid belt receiving $100-400 \mathrm{~mm}$ annual rainfall (CIHEAM 2009). They provide forage resources as well as many ecosystem services including carbon sequestration, protection against soil erosion, increased water infiltration and biodiversity preservation (Turner et al. 2011). However, in the southern Mediterranean countries, areas available for grazing are diminishing due to the expansion of production of rainfed annual cereals, to meet increasing demand for human food (Lelievre and Volaire 2009). Millions of hectares of fallow and rangeland have disappeared while stocking rates increased due to imported grains and by-products subsidised by governments. Thus, grazing at higher stocking rates is allocated to drier and poorer rangelands: the remaining rangeland is drastically degraded due to overgrazing, leading to a dramatic loss of biodiversity, vegetation cover, greater soil erosion and a diminishing ability to provide ecosystem services.

Perennial grasses dominate in most natural grasslands and provide the principal nutrition for ruminant livestock. However, the genetic diversity of these palatable species is declining due to habitat destruction and overgrazing (CIHEAM 2009). In the Northern Mediterranean countries, stocking rates tend to decrease along with an increase of extensive permanent pastures that cannot provide sufficient forage resources in all seasons. As a consequence, and around the whole Mediterranean Basin, complementary forage crops are crucial to secure farming systems and increase productivity and stability of animal production.

\subsubsection{The case of the Southern Great Plains of the USA}

According to the recent report of the U.S. Global Change Research Program (Karl et al. 2009), climate change is projected to progress in the USA during this century. USA average temperature has risen more than $1{ }^{\circ} \mathrm{C}$ over the past 50 years, and further temperature increase will depend on the amount of greenhouse gases emitted globally and climate sensitivity to those emissions. By the end of the century, the average USA temperature is projected to increase by approximately 4 to $6{ }^{\circ} \mathrm{C}$ under the higher emissions scenario or by approximately 2.2 to $3.6{ }^{\circ} \mathrm{C}$ under the lower emissions scenario. Future changes in total precipitation are more difficult to project than changes in temperature. For example, climate models suggest that northern areas are likely to become wetter, and southern areas drier, especially in winter and spring. The models also agree that much of the Southeast and West will experience reductions in precipitation and increases in drought severity and duration. These changes will have dramatic effects on agricultural production (Motha and Baier 2005).
In the Southern Great Plains of the USA, located between latitudes $32^{\circ}$ and $38^{\circ} \mathrm{N}$, a bimodal pattern of precipitation with peaks in May and September, severe water deficits accompanied by extreme heat in summer and relatively mild winters have shaped the primary and secondary productions from agroecosystems. One of the most important crops with the ability to compensate for these weather extremes is winter wheat (Triticum aestivum L.), cultivated on approximately 6.5 million hectares (Pinchak et al. 1996). In this region, wheat is a dual-purpose crop (31\% for grain-only, $20 \%$ for forageonly and $49 \%$ for dual-purpose use) providing winter forage for cattle and a grain crop at maturity in early summer (Hossain et al. 2004). In the past decade, the disturbed pattern of autumn precipitation has threatened timely planting of dualpurpose wheat, often resulting in a lack of forage for cattle to graze into the winter and early spring. In the 1970s and 1980s, introduced cool-season but summer-active perennial grasses became an important source of high-quality forage to complement dual-purpose wheat and perennial warm-season $\mathrm{C} 4$ grass pastures, saving producers about US $\$ 100 \mathrm{ha}^{-1}$ annually (Reuter and Horn 2002). Changing climatic conditions (Nielsen-Gammon 2011) is considered one reason for the increasing failure of these summer-active, introduced, coolseason perennial grasses which are at the margin of their zone of adaptation in these naturally $\mathrm{C} 4$ grass-dominated ecosystems (Malinowski et al. 2003; Gillen and Berg 2005). As a result, improved cool-season perennial grasslands based on summer-active cultivars are short-lived and require frequent reestablishment, increasing the cost of winter forage for cattle and driving the search for alternative forage options.

\subsection{The role of $\mathrm{C} 3$ versus $\mathrm{C} 4$ perennial forage grasses}

For the development of sustainable pastures in the light of these warming projections, the question arises regarding the relative importance of $\mathrm{C} 3$ and $\mathrm{C} 4$ grasses in future Mediterranean and temperate summer-dry environments. The current role of $\mathrm{C} 3$ grasses in grazing animal breeding and production in these regions is critical, and while the forage contribution of C4 species may increase (Johnston 1996), the role of $\mathrm{C} 3$ species is likely to remain important even as the climate warms, for the following reasons. $\mathrm{C} 3$ species generally have a lower optimum temperature for peak growth than $\mathrm{C} 4$ grasses (Pau et al. 2013; Still et al. 2003). These grasses are better adapted to the lower radiation intensity of the cooler seasons with maximum growth at lower temperatures and vapour pressure deficits when water use efficiency is higher (Lelièvre et al. 2011). In addition, the forage of $\mathrm{C} 3$ grasses is of markedly higher nutritive quality than that of most $\mathrm{C} 4$ species with resulting benefits for animal production (Minson 1990; Minson and McLeod 1970). C4 grass species have the disadvantage that they produce little forage during the cooler seasons because of sub-optimal temperatures and radiation 
intensity. This was recently demonstrated in a comparison between a suite of $\mathrm{C} 3$ and $\mathrm{C} 4$ grasses at multiple sites across temperate southern Australia (Reed et al. 2008b). In addition, C4 species tend to be much more sensitive to frost, in some cases to such a degree that frost can destroy their entire swards. The cold, often wet soils to which all the grasses were exposed in this multi-site experiment also had a deleterious effect on $\mathrm{C} 4$ grass persistence. Thus, the $\mathrm{C} 3$ grasses in the same study as that of Reed et al. (2008b) had superior persistence compared to all $\mathrm{C} 4$ grasses except Pennisetum clandestinum (Nie et al. 2008). Nevertheless, there is little doubt that drier and warming climates will pose serious challenges to persistence of many of the current $\mathrm{C} 3$ grass cultivars used in these regions. The question, 'In a warming climate is there still an important role for cool-season perennial pasture grasses in the future, or should the focus be redirected to $\mathrm{C} 4$ warm season species', is pertinent and has a different answer in different regions. Thus, in those regions with mild winters, including south-west Western Australia and the northern inland New South Wales region of south-eastern Australia, significant development of pasture technology based on C4 warm-season grasses is occurring. While some of this development is based on the perception that such species will be better adapted to future climates (Timbal et al. 2006; Charles and $\mathrm{Fu} 2012$ ), some is based on observations that there are few well-adapted, persistent $\mathrm{C} 3$ cool-season grasses available to commercial agriculture particularly in northern NSW where summer rainfall predominates (Culvenor and Boschma 2005). Indeed, early indications in northern inland NSW suggest that C4 grass species have better adaptation (Harris et al. 2009) although in the cooler, frost-prone Tableland districts of this region $\mathrm{C} 3$ grasses are likely to remain dominant. However, even with a warming and drying climate for much of the Mediterranean Basin, southern Australia and the Southern Great Plains of USA, cool-season, C3, perennial grasses are likely to remain important for farmers with grazing livestock both in terms of environmental adaptation and livestock production. Nevertheless, it will be necessary to strengthen the environmental resilience of these grasses especially by enhancing their tolerance to drought and heat.

This review will identify research required to maximise the development and use of cool-season grasses with enhanced adaptation to drought and high temperature and highlight technical and regulatory constraints to the release and adoption of these grasses.

\section{Strengthening drought survival strategies of perennial grasses}

An increased frequency and severity of drought, defined here as 'a period of sub-optimal moisture availability reducing potential plant productivity and in severe cases threatening plant survival' (Passioura 2006) along with raised temperatures, are likely to be two key factors threatening the productivity and stability of cool-season grasslands and sown pastures in the future. These two factors also interact with one another so that as temperature rises (other things being equal), so also does vapour pressure deficit which in turn increases the rate of transpiration from plants per unit of $\mathrm{CO}_{2}$ uptake, leading to a reduction in water use efficiency (Ritchie 1983) and increasing the rate at which water deficit stress is experienced.

The majority of research on the effects of water deficit has dealt with annual rather than perennial crops so that the conceptual framework necessary to understand drought resistance and survival in perennial grasses has been slower in developing than that for annual crops. The 'drought resistance framework' of Turner (1986; 1997, 2003), although developed primarily with annual crops, seeks to identify the specific physiological and biochemical characteristics that lead to improved plant yields in drought-prone environments. The strategies these characteristics comprise are termed drought escape, dehydration avoidance (syn. postponement, delay) and dehydration tolerance (Turner 1986; 1997). In the case of perennial grasses, plants able to resist moderate drought and maintain aerial growth have to avoid and/or tolerate leaf dehydration. Conversely, plant responses facilitating survival of severe drought are mainly associated with both dehydration avoidance and tolerance primarily occurring in meristematic tissues, as these may be the sole plant organs surviving severe drought. In some species and genotypes, summer dormancy is another combination of strategies which confers efficient survival of meristematic tissues through the dehydration avoidance and tolerance of these organs (Volaire and Norton 2006). Making this distinction between the responses of mature and meristematic tissues seems crucial to properly analyse and understand the strategies of perennial grasses to contrasting drought intensities (Volaire et al. 2014). These various drought resistance and survival strategies as used by perennial cool-season grasses are graphically depicted in Fig. 1.

\subsection{Drought escape- the importance of reliable seed production}

At the whole plant level, 'drought escape' is a strategy primarily used by annual plants to ensure that growth, reproduction and seedset are completed before the onset of dry conditions, with the plant existing as a seed during the season when abiotic conditions are most threatening to survival (Kooyers 2015) An example of how 'drought escape' has been a key breeding objective is seen in the Australian wheat industry where plant breeders have sought to better match plant phasic development to the environment. For the relatively dry Australian environments, in contrast to Europe, this has 
Fig. 1 Plant adaptive strategies and responses at the whole plant level (aerial and root growth, leaf senescence) involved in drought resistance and drought survival successively, under increasing drought intensity. Drought resistance is defined as the plant ability to maintain biomass production (at leaf level) under moderate drought while drought survival is the ability of meristems and apices to survive and regrow upon conclusion of drought after rehydration (source Volaire et al. 2014 EJA, with permission from publisher)

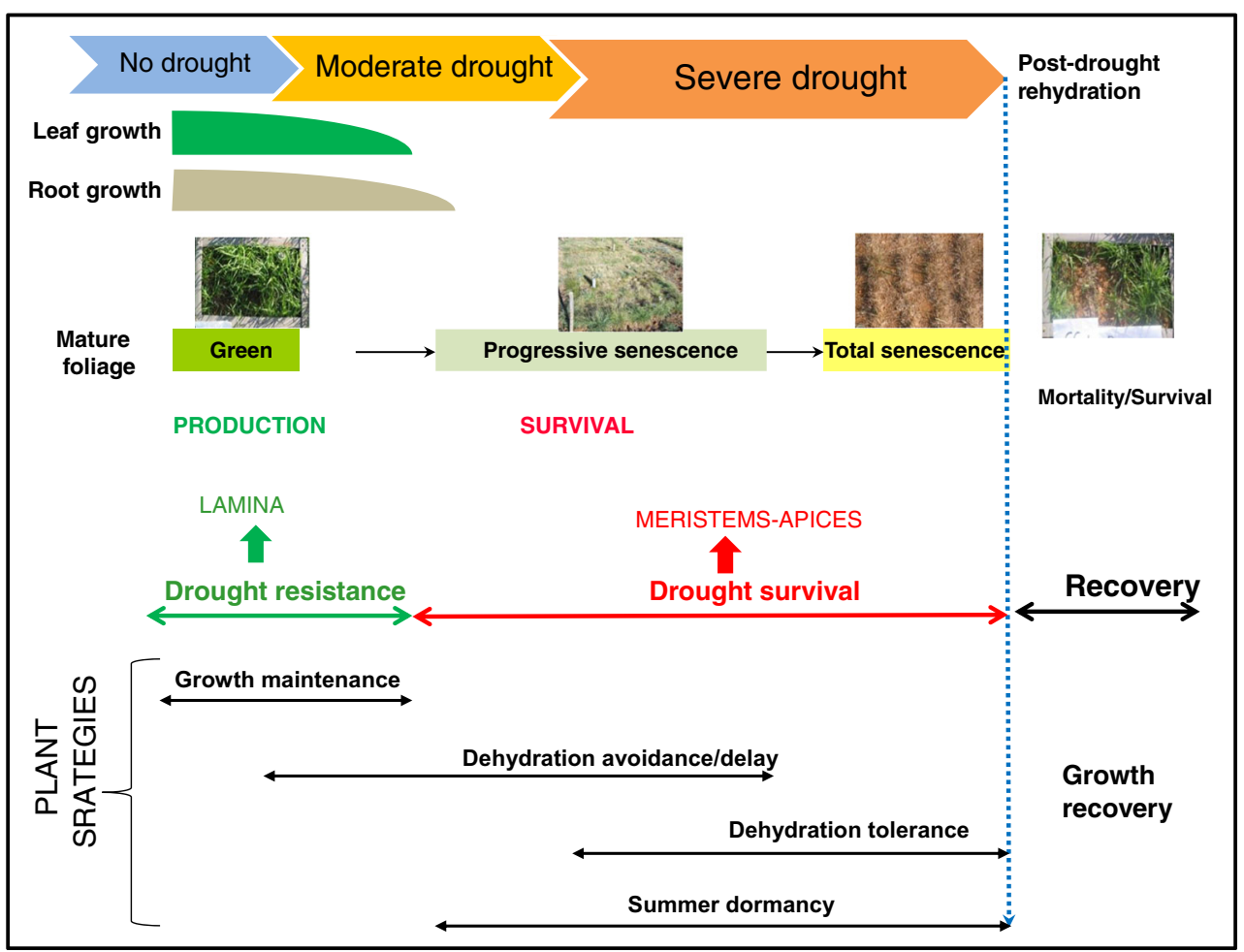

required the development of earlier maturing cultivars. While perennial plants cannot escape from stressful seasons, the correct phasing of flowering and seedset to ensure that these processes occur at a time of year when they can be successfully completed is essential to long-term survival. Thus, a positive correlation between earliness of heading and ability of plants to survive subsequent drought has been shown in cocksfoot (Volaire and Lelievre 1997).

\subsection{Dehydration avoidance/delay and rooting system improvement}

While drought-escaping species only grow with sufficient water supply, the extent to which a plant regulates its water potential as soil water deficit increases indicates whether a species copes with water deficit by responses primarily characteristic of either dehydration avoidance or dehydration tolerance (Kramer 1980; Levitt 1980). Thus, a species is considered to use dehydration avoidance (syn. dehydration delay/ postponement) if it must maintain high tissue water potential during periods of moisture deficit. Traits characteristic of the dehydration avoidance strategy include high sensitivity of stomatal conductance to water deficit, osmotic adjustment, conservation of water through leaf modifications such as rolling, paraheliotropism and waxiness to reduce heat load and transpiration as shown in a range of grass species from both the North American semi-arid prairies (Hardy et al. 1995) and Australian rangelands (Bolger et al. 2005).
In phalaris, the early onset and high level of senescence of herbage were observed to reduce transpiration (McWilliam 1968) while the development of an extensive root system and/or superior hydraulic conductance to maximise soil water uptake was noted as being important for ongoing production under drying conditions in tall fescue (Garwood and Sinclair 1979). Dehydration-avoiding plants are able to survive extended dry spells but can only do so if able to maintain high tissue water status. Indeed, McWilliam and Kramer (1968) demonstrated in phalaris that dehydration avoidance through the development of an extensive, deep root system (Cashmore 1934) and the ability to readily senesce foliage during summer is of great importance for the maintenance of the high plant water content that is typically observed in this grass. They showed that if this water harvesting ability is compromised by severing the root system, the plants rapidly die.

Although research to develop roots of annual cereals better able to optimise yield in water-limited environments continues apace with examples already in wheat (Palta et al. 2011; Wasson et al. 2012), this work remains to be commenced in perennial forage grasses. Techniques to facilitate screening of roots across genotypes have been developed utilising both destructive and non-destructive methods (Flavel et al. 2012), with the common objective of improving the adaptation of crops to both the biotic (Watt et al. 2003; Sprague et al. 2007) and abiotic soil factors (Rahnama et al. 2011) which induce stress. These techniques need to be applied in the development of perennial forages to strengthen root systems and 
thereby enhance plant persistence, although so far few of the more advanced phenomic techniques have been applied with these species (Walter et al. 2012). Enhanced dehydration avoidance, for example through denser or deeper rooting, may be useful in many situations of water deficits (Fig. 2). Thus, in south-eastern Australia, summer rainfall is predicted to increase leading to the possibility that subsoil moisture may accumulate over summer so that cool-season grasses which can access this moisture from depth could have improved productivity and persistence.

\subsection{Dehydration tolerance to improve survival of drought}

A species is considered to use dehydration tolerance as a strategy if it allows its water potential to fall in response to increasing moisture deficit (Levitt 1980). The primary indicator of dehydration tolerance is the level of the plant water content at death, i.e. lethal plant water content. Specifically, dehydration tolerance increases as lethal water content declines (Flower and Ludlow 1986, 1987). This trait seems to be mediated by mechanisms which maintain the integrity of cell membranes as tissue moisture content declines. LEA proteins including

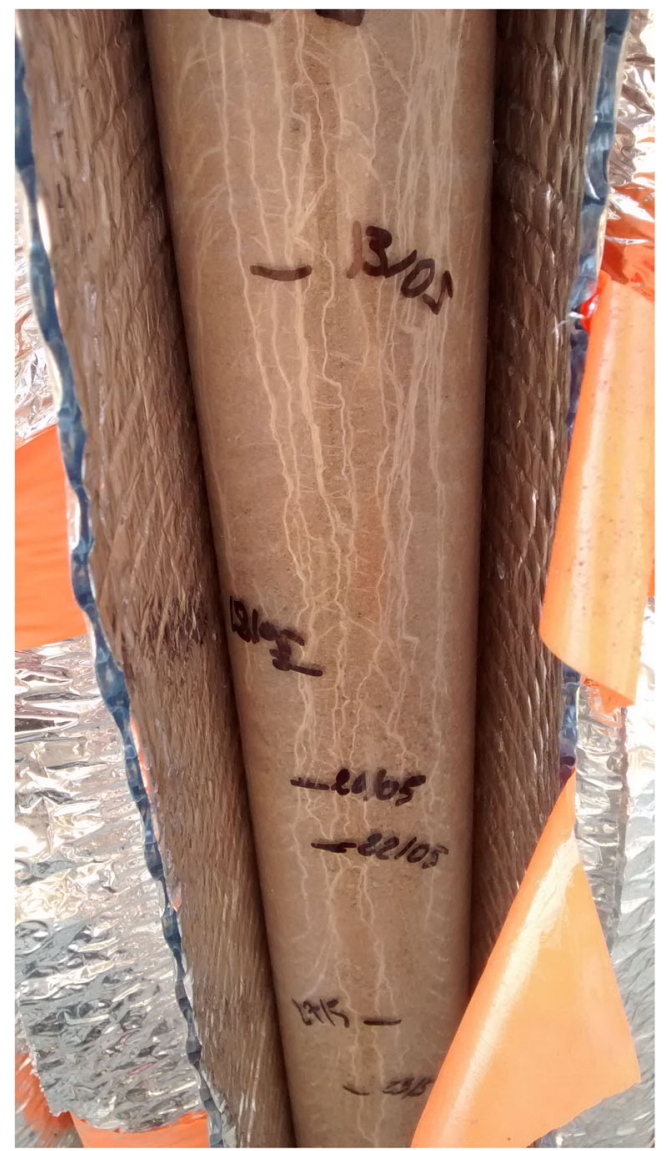

Fig. 2 Assessment of intra-specific variability in the root system and root traits of cocksfoot dehydrins, sugars such as fructans (Demel et al. 1998) and the level of reactive oxygen species have been implicated in this trait (Turner 2003) although research to better understand its biochemical and molecular basis is required (Verslues et al. 2006; Oliver et al. 2010). Plants with high leaf dehydration tolerance typically maintain growth for longer into a dry period than a dehydration avoider, and although often associated with development of an extensive root system, they tend not to shed their foliage to the same degree as dehydration avoiders and so are better able to utilise incident rainfall for growth if and when it occurs.

Among the perennial grasses, cocksfoot (irrespective of whether a summer-dormant or summer-active cultivar) is more dehydration tolerant at the meristem level than either tall fescue or phalaris. Thus, the meristems of cocksfoot were reported to dry to approx. $0.54 \mathrm{~g} \mathrm{H}_{2} \mathrm{O} / \mathrm{g}$ dry weight during a drying cycle, whereas those of tall fescue dried down to 0.72 while phalaris dried to $0.70 \mathrm{~g} \mathrm{H}_{2} \mathrm{O} / \mathrm{g}$ dry weight immediately before death (Norton et al. 2014). Related to this greater dehydration tolerance is the ability of cocksfoot to survive at soil moisture contents lower than either tall fescue (Volaire and Lelievre 2001) or phalaris (Norton et al. 2014). However, the processes involved in the ability of the perennial herbaceous plant to survive and recover after tissue dehydration require better characterisation (Craine 2013; Hoover et al. 2014). In particular, the hydraulic thresholds of mortality in perennial grasses should be investigated with recent methodological developments that allow the measurement of vulnerability to cavitation associated with drought survival in trees (McDowell et al. 2008; Reich 2014) (Lens et al. 2013). Over the last decade, methods to measure dehydration tolerance in forage crop species have evolved (Volaire and Lelievre 2001) and these have been extended to, Poa bulbosa L. (Volaire et al. 2001), and modified to compare the dehydration tolerance of perennial grasses with barley (Volaire 2003) and wheats of both annual and perennial habit (Larkin et al. 2014). More recently, a glasshouse-based method to measure and scale dehydration tolerance incorporating the components, (1) final soil water content, (2) duration of survival after stomatal closure and (3) percentage of surviving plants, has been developed and has been used to compare for the first time the three cool-season perennial grasses most important in regions with Mediterranean climates, tall fescue, cocksfoot and phalaris (Norton et al. 2014). This method not only highlighted the differences that occur between species but also identified intra-specific variation, e.g. within phalaris, and so can be of use to plant breeders. This method needs further refinement particularly to be able to account for differences in plant vigour after termination of the drying cycle and should possibly be further extended to include final tissue moisture content in the determination. It also needs to be modified to accommodate larger numbers of genotypes and perhaps, most importantly, needs field validation. Nevertheless, the method offers 
the potential to screen for this trait which is important for both forages and annual crops. One of the areas of greatest applicability might be in screening seedlings of genotypes for differences in survival under drying soil conditions. Given the need to sow many cool-season crops in early autumn, e.g. dual-purpose grain/grazing cereals and canola (Brassica napus $\mathrm{L}$.), with the consequent high risk of dry soil conditions post-sowing, any difference in the ability of the seedling of one genotype to survive over another confers the potential to maintain a satisfactory crop density and thus yield potential.

Desiccation tolerance, which could be considered as an extreme form of dehydration tolerance, is the ability of plant tissues to maintain viability and recommence growth upon rehydration after tissues have become air dry. It has not been observed within the important cultivated $\mathrm{C}_{3}$ perennial pasture grasses, including cocksfoot, perennial ryegrass (Volaire 2002; Volaire et al. 1998), tall fescue (Volaire and Lelievre 2001) or phalaris (McWilliam and Kramer 1968; Norton et al. 2014).

\subsection{Summer dormancy to improve survival of extended, extreme drought}

Summer dormancy is defined as an endogenously controlled and coupled series of processes comprising the cessation or reduction of leaf growth, the complete or partial senescence of herbage and, in some cases, the endogenous dehydration of meristems (Volaire and Norton 2006). These responses are expressed consistently under the environmentally inductive conditions typical of Mediterranean summers and also under non-limiting water conditions (Volaire and Norton 2006; Norton et al. 2008). The trait is induced under the short photoperiods and low temperatures of Mediterranean climate winters with studies showing that cocksfoot and tall fescue must be exposed to these conditions for the trait to be fully expressed under the subsequent long photoperiods and high temperatures of summer (Norton et al. 2006a; Norton et al. 2006b). Summer dormancy is a trait which has evolved primarily for enhancing plant survival and is expressed by some of the cool-season perennial grasses mainly originating in semi-arid and arid Mediterranean climates where the summer-dry period typically lasts 4 months or more (Cooper 1963). Recent research has demonstrated this trait to be very powerful in improving survival over long and intense dry spells in the field with a suite of papers demonstrating the utility of the trait in cocksfoot and tall fescue in the Mediterranean Basin (Volaire 2002; Volaire et al. 2005; Norton et al. 2006a; Norton et al. 2006b; Shaimi et al. 2009; Pecetti et al. 2009; Annicchiarico et al. 2011), southern USA (Malinowski et al. 2005; Malinowski et al. 2009) and southeastern Australia (Culvenor and Boschma 2005; Norton et al. 2001; Hackney et al. 2006; Hayes et al. 2010a).

The potency of the summer dormancy trait in ensuring survival and thus maintaining the density of the pasture sward was well demonstrated in cocksfoot and tall fescue cultivars contrasting in expression of this trait over a number of dry periods of over 3 months which subjected swards to cumulative evapotranspiration (CE) levels of from 650 to $870 \mathrm{~mm}$, the last dry period coinciding with the severe dry spell and heat wave that afflicted much of western Europe in the summer of 2003 (Norton 2007). Over the dry spells of 650 and $790 \mathrm{~mm} \mathrm{CE}$, the summer-dormant cocksfoot Kasbah and the non-dormant but drought tolerant Mediterranean cv Medly maintained their sward densities. However, when the drought intensity was increased to $870 \mathrm{~mm} \mathrm{CE}$, while the Kasbah sward remained unchanged, Medly was unable to maintain its pre-summer sward cover experiencing a decline to $78 \%$ of its original density (Norton et al. 2006a). Under the dry spell of $790 \mathrm{~mm}$ $\mathrm{CE}$, the temperate cocksfoot cultivar Lutetia could only maintain $39 \%$ of its pre-drought cover in contrast to both Kasbah and Medly which remained unchanged. The robust drought tolerance of cv Medly under moderately severe droughts and the poor drought survival of Lutetia have been subsequently confirmed by Poirier et al. (2012). More recent observations in Australia have again highlighted the ability of the summer dormancy trait to enhance survival. Thus, after an extended dry period over the spring/summer period of 2012/2013 during which cumulative evapotranspiration totalled $880 \mathrm{~mm}$, cv Kasbah had been able to maintain $51 \%$ basal cover while other less dormant hispanica populations had declined to $24 \%$ cover with the intermediate cv Currie able to maintain only $12 \%$ cover (Culvenor et al. 2016).

In an earlier study with tall fescue, the summer-dormant $\mathrm{cv}$ Flecha maintained $100 \%$ of its pre-summer sward density under the dry spells of 650 and $790 \mathrm{~mm} \mathrm{CE}$ with a slight decline to $98 \%$ cover when drought intensity increased to $870 \mathrm{~mm}$ CE. In contrast, the non-dormant cultivar Demeter could only keep $75 \%$ of its pre-summer sward alive under both the 650 and $870 \mathrm{~mm} \mathrm{CE}$ droughts (Norton et al. 2006b). Such observations as these, particularly in the light of impending changes in the climate toward a drier and hotter future, have convinced many pasture scientists that the summer dormancy trait merits greater exploitation both for forage production and to help maintain agricultural system sustainability. Figure 3 illustrates the relationships between drought intensity and grass survival as influenced by the drought strategy used by the particular genotype. These relationships are depicted under current and a potential future climate change scenario and are influenced by the level of soil water available.

Before the full potential of the summer dormancy trait can be realised, some pressing problems must be addressed. These have been well summarised by West et al. (2009) who observed that the trade-off between high summer dormancy expression and low forage yield, often also associated with early flowering, must be broken (Knight 1965). As dormancy, by definition means absence of growth, this goal may be considered unrealistic. This is because the three attributes, high dormancy, long 
Fig. 3 Present and future adaptation of the perennial forage species, cocksfoot and tall fescue, depending on their drought adaptation strategies and according to $(x)$ current (green) and future $(\mathrm{red})$ average cumulative water deficit across spring and summer $(P$ precipitation, ETP potential evapotranspiration) as influenced by $(y)$ the soil water reserve

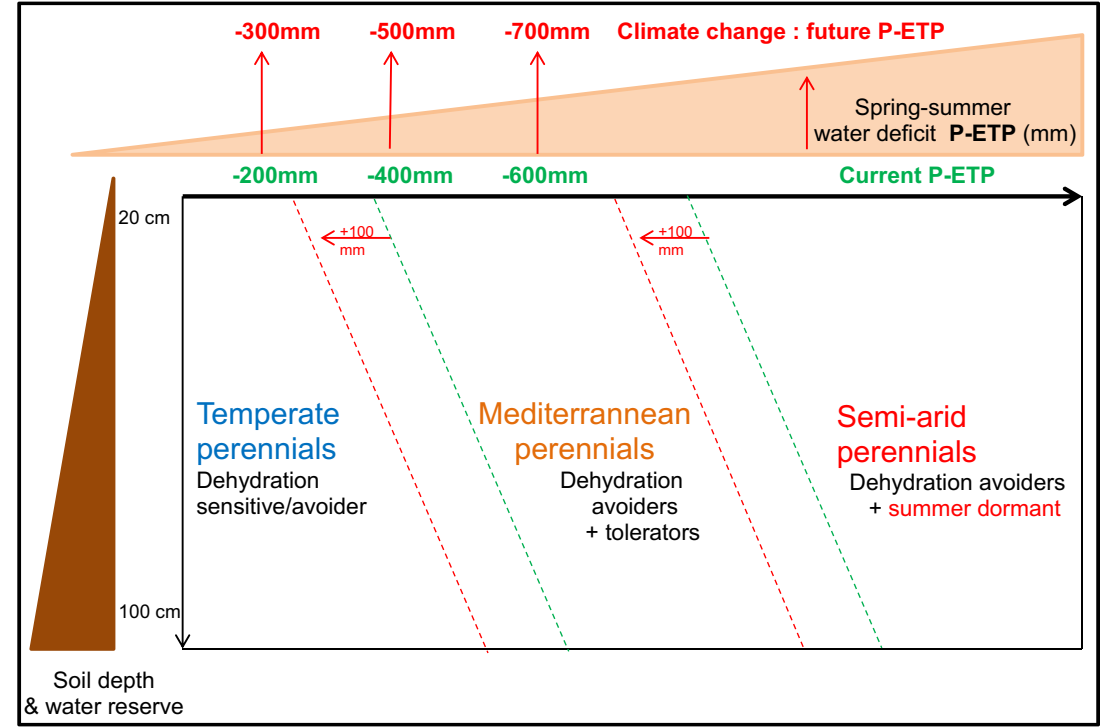

duration of dormancy and early flowering, almost always seem strongly correlated. Given the potency of the dormancy trait, it would potentially be attractive if a cultivar with comparable dormancy to cocksfoot cv Kasbah could be developed which would only be inactive for 3 months rather than the 5-month period exhibited by Kasbah. The low forage productivity of many summer-dormant populations is a disincentive to adoption of cultivars with this trait, even though the superior persistence of these plants provides some compensation to this drawback. In this context, the recent publication of research exploring the possibility of breaking this trade-off is timely (Kallida et al. 2016). Even though these researchers observed that high summer dormancy was negatively correlated with annual biomass production $(-0.34, P<0.005)$, they did note that some progeny had both high dormancy and high productivity indicating the potential to break this trade-off. It is interesting to note that comparable research to this with similar results had occurred with phalaris more than 30 years previously (Oram 1984). Phalaris is not commercially important in the Mediterranean Basin, but as it originates from that region, it is reasonable to assume that its ecophysiological responses and associated genome have many similarities. Scientists specialising in cocksfoot or tall fescue would therefore be wise to note knowledge advances in phalaris.

The second knowledge gap, related to the first, concerns the generally poor understanding of the environmental controls causing induction, expression and release of summer dormancy. Related to this is the lack of information about the relationship between flowering and dormancy induction, and this has important implications because it influences key management decisions such as sowing time. Questions including whether dormancy can be induced independent of flowering need to be addressed. Filling these gaps becomes critical particularly if there is a desire to use the trait in environments where to date it has not been used (West et al. 2009).
P. bulbosa (Ofir 1986; Ofir and Dorenfield 1992; Ofir and Kerem 1982; Ofir and Kigel 1998, 1999, 2003; Ofir and Kigel 2006) and Hordeum bulbosum (Ofir 1975, 1976, 1981; Ofir and Koller 1972, 1974; Ofir et al. 1967) are the summer-dormant grasses about which most is known regarding controls over dormancy. This research has mainly been performed in a phytotron. To more efficiently use this trait in the commercially important forage grasses including cocksfoot, tall fescue and phalaris, research in these species directed at a greater understanding of the trait is necessary. The research to tackle both of these problems should be directed not only at understanding environmental controls but also focus on the biochemical and genetic aspects of trait induction, expression and release with effects on productivity explained. Indeed, in phalaris, while the positive contribution of deep roots to dehydration avoidance and the associated drought survival is clear, it still remains to be definitively demonstrated whether and how much summer dormancy enhances drought survival (Norton et al. 2012).

Another problem relates to the difficulty of reliably phenotyping summer dormancy in tall fescue. To date, only lower levels of summer dormancy, termed 'incomplete summer dormancy', have been observed in populations of tall fescue in contrast to cocksfoot which contains populations expressing higher levels of dormancy, termed 'complete summer dormancy' (Norton et al. 2008; Volaire and Norton 2006) (Fig. 4). Preliminary research has begun to address the difficulty of accurately phenotyping summer dormancy in tall fescue (Bhamidimarri et al. 2012). However, extra research is needed to improve the reliability of trait measurement in this species addressing such questions as definition of the appropriate environmental conditions for phenotyping. There is a strong case for collaborative research between scientists from different regions of the world to work together to address this problem. A measurement system comparable to that developed to assess fall dormancy in lucerne (alfalfa, Medicago 


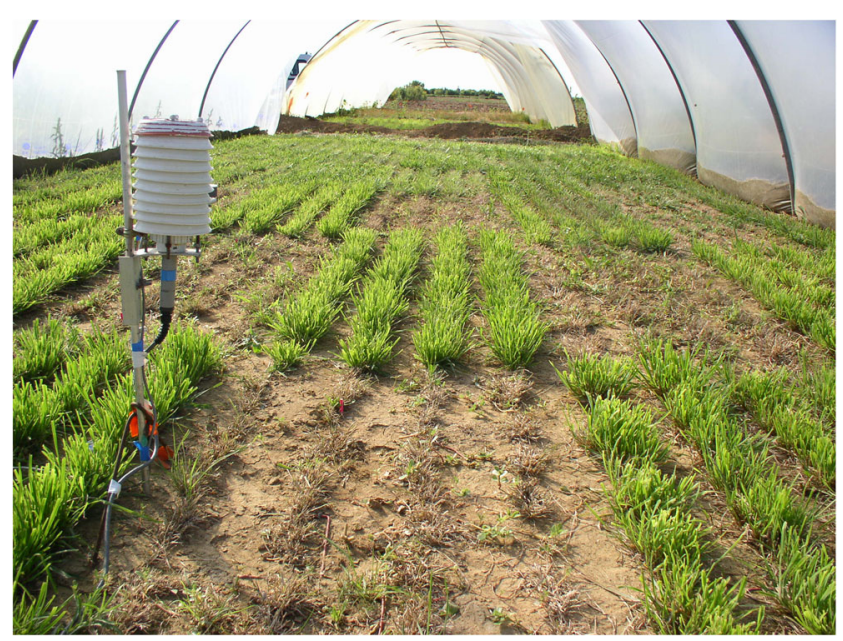

Fig. 4 Measurement of summer dormancy expression in the field under full irrigation over summer. The green, actively growing swards are the Mediterranean cocksfoot cv Medly, whereas the adjoining, senescent swards belong to the highly summer-dormant cocksfoot cv Kasbah

sativa L.) would be an appropriate goal because this system has been uniformly accepted and used among researchers and it has contributed to the progress evident in that very important forage species (Teuber et al. 1998).

Another hurdle in the development of summer-dormant grass technology is the requirement for farmer management packages to allow the establishment and maintenance of compatible, stable grass/legume mixtures (Butler et al. 2008; Butler et al. 2011). This can be particularly problematic at establishment because in grass/legume mixtures, farmers have very few herbicide options for weed control and the young seedlings can easily be out-competed by aggressive weeds (Dear et al. 2007). An understanding of the growth rhythms of all pasture components whether of annual or perennial habit will also be important in selecting the most suitable companion for the summer-dormant grass. The appropriate genotypic components of these mixtures will vary across climatic gradients. The development of principles to guide the degree of expression that must be exhibited by a trait to ensure plant survival in any particular environment will be necessary. For example, to know how much summer dormancy expression is required for a grass to survive in a $400-\mathrm{mm}$ rainfall Mediterranean semi-arid climate may well be necessary.

Finally, as research has not addressed the effects of summer dormancy on reproductive growth, this must occur to ensure commercial availability of seed of cultivars with this trait. Given the central importance of successful seed production to the commercial survival of any cultivar, and the failure to produce adequate seed supplies of key forage species, e.g. cultivars of Dactylis glomerata ssp. hispanica, there is a clear need for plant breeders and agronomists to place greater emphasis on the development of cultivars with a seed yield high enough for them to be commercially attractive. The unreliability of seed yields is also cited by seed growers of summer- dormant tall fescue cultivars as a constraint to seed supply chain certainty. The concurrent development of agronomic management guidelines to assist seed producers is clearly essential.

\subsection{Drought tolerance- the role of endophytes}

Plants of native tall fescue populations are often hosts to symptomless fungal endophytes of the genus Epichloë coenophiala (Leuchtmann et al. 2014), formerly Neotyphodium coenophialum (Hill et al. 1990; Ball et al. 1993). Indeed, there is growing evidence that Epichloë spp. endophytes have played a substantial role in the evolutionary adaptation of cool-season perennial grasses to drier and hotter regions of southern Europe (Lewis et al. 1997; Lewis 2000). There is an increasing body of literature describing complex morphological, physiological and metabolic adaptations of cool-season grasses to a broad range of abiotic and biotic stresses as a result of associations with these endophytes (Malinowski and Belesky 2000; Saikkonen et al. 2004). These studies focused almost exclusively on the interactions between grasses originating from the more northern zones of origin, for which symbiosis with the endophytes became vital to their survival in drier and hotter environments. It has been proposed that tall fescue evolved separately north and south of the Mediterranean Sea, as suggested by a lack of crosscompatibility between ecotypes collected in the two regions (Hunt and Sleper 1981; Sleper 1985). Indeed, DNA sequence analysis grouped tall fescue into the southern ecotypes (originating from North Africa, Western Mediterranean, Iberia and southern Italy, bounded in the north by the Pyrenees and the Alps) and northern ecotypes originating from northern Europe into Iberia, Morocco and northern Italy (Craven et al. 2005). Both tall fescue groups harbour the endophytes; however, the endophytes (designated FaTG-2 and FaTG-3) in some of the southern ecotypes of tall fescue (from southern Spain, Algeria and Sardinia) are genetically, biochemically and morphologically different from E. coenophiala (Christensen et al. 1993; Clement et al. 2000; Piano et al. 2005). E. coenophiala is commonly found in northern tall fescue and in those tall fescue lineages introduced from northern Europe into North America, Australia and New Zealand (Craven et al. 2009).

The role of endophytes in summer-dormant tall fescue is far less understood. The infection frequency of native accessions of summer-dormant tall fescue is usually high (Clement et al. 2001; Piano et al. 2005; Pecetti et al. 2007), suggesting an important ecological role similar to that in continental tall fescue ecotypes. In fact, some of the benefits of endophyte infection are similar for both fescue types, i.e. in terms of tolerance to soil mineral imbalance (Malinowski et al. 2004). Because summer-dormant tall fescue already possesses a highly efficient mechanism of drought avoidance, one may speculate that infection with endophytes would not add 
significant improvement in drought tolerance as it is observed for continental tall fescue (Malinowski et al. 2005). Assuero et al. (2000) observed a beneficial role of endophytes for both continental and Mediterranean tall fescue genotypes under controlled growth conditions. In contrast, Flecha summerdormant tall fescue grown in north Texas for several years did not express any significant increase in persistence whether infected with the endophyte or not (Malinowski et al. 2005; Malinowski et al. 2009). However, after devastating long-term droughts in Texas during 2010-2014, for the first time, a significant positive effect of an endophyte strain (AR584) on survival of an experimental summer-dormant tall fescue breeding line was observed (Malinowski, unpublished data).

Future research should identify novel endophyte strains compatible with summer-dormant tall fescue cultivars similar to those achieved for summer-active tall fescue (Bouton et al. 2002). Studies evaluating effects of the most common novel endophyte strains AR501, AR542 and AR584 on biochemistry and physiology of summer-dormant tall fescue confirm, with the exception of the horse (Bourke et al. 2009), a lack of tall fescue toxicoses in grazing animals (Simpson and Mace 2012; Young et al. 2015). However, altered patterns of bioprotective alkaloids in tall fescue plants infected with the novel endophytes may result in insufficient protection of host grasses against certain insects (Hunt and Newman 2005) that may have unknown long-term consequences for stability of novel associations in managed agroecosystems.

\section{Regulatory constraints to use of drought tolerant cool-season grasses-putative weed potential}

In the USA, there is currently concern that the introduction of summer-dormant tall fescue may result in the species becoming invasive to native flora. Continental (summer-active) tall fescue was introduced to the USA in the 1800s (Hoveland 2009), and it has become the most important cultivated pasture grass, occupying over 15 million ha (Buckner et al. 1979). Continental tall fescue is a strong competitor with native vegetation, and it has been reported being invasive in Arkansas, Georgia, Idaho, Missouri, New Jersey, Oklahoma, Tennessee, Washington and Wisconsin (USDA-NISIC 2013; USDA-NRCS 2013).

Summer-dormant tall fescue is genetically (Craven et al. 2005) and physiologically (Norton et al. 2006b) distinct from the summer-active variant; thus, its potential to be invasive should not be considered similar. These grasses evolved in association with annual species in Mediterranean grasslands (Naveh 1960). Annual species dominate these plant communities and complete their growth cycles before the onset of summer drought, thus minimising competition for limiting resources with the summer-dormant grasses (Fernández-Alés et al. 1993). Preliminary research suggests that summerdormant grasses originating from the Mediterranean Basin and introduced to Mediterranean environments of California have very limited potential for invasiveness when compared with introduced Mediterranean annuals and native summerdormant grasses (Vaughn et al. 2011). Thus, initial attempts to establish and grow lucerne and summer-dormant tall fescue mixtures in north Texas and southern Oklahoma have proven unsuccessful (Stein et al. 2009). Malinowski et al. (2011) also observed that summer-dormant tall fescue was less competitive than continental tall fescue when both types were grown in binary mixtures with alfalfa, especially when constrained by low soil moisture availability in summer. Summer-dormant tall fescue may be able to coexist only with species expressing a similar growth pattern (Malinowski et al. 2008) and may not be tolerant of a summer-active competitor (Assuero et al. 2002). In non-native environments such as those of the Southern Great Plains, summer-dormant tall fescue is not expected to be able to take advantage of summer soil moisture, in contrast to native temperate and warm-season flora, because its growth pattern is highly restricted. Therefore, summer-dormant tall fescue is not likely to become invasive in environments dominated by warm-season perennial and annual plant species that actively grow during summer when soil moisture is available.

It is true that the introduction of exotic forage species has in some cases led to them becoming invasive weeds, and caution and responsibility need to be exercised in this activity. However, it is possible to ascertain the potential invasiveness of a plant during initial field evaluation so that this introduction can be halted if danger signs, e.g. aggressive spreading into neighbouring plots, occur. The experience in other environments where summer-dormant grasses have been introduced should inform consideration of this issue. The first summer-dormant cultivars in Australia were commercialised in the late 1960s/early 1970s when the cocksfoot cultivars Kasbah and Berber, tall fescue cv Melik and phalaris cv Sirocco were released (Oram 1990). It is important to note that the introduction and release of these exotic plants into diverse southern Australian environments have not led to the development of any of these cultivars into environmental weeds. This contrasts with the situation of summer-active phalaris cultivars which are regarded as showing weed potential in some situations in higher rainfall areas (Carr et al. 1992). Considering the important advantages that grasses with the summer dormancy trait confer particularly in terms of drought survival, and the low likelihood of negative impacts, it should be questioned whether current controls over release of grasses with this trait are warranted.

\section{Conclusion and future directions}

This paper has highlighted research issues which can mainly be classified as questions of clarification of the phenomics of these species. The addressing of these questions will assist in 
the more rapid deployment of genomic selection, which offers much, but so far has delivered little in the improvement of forage species (Barth 2012). A major reason for the slow uptake of these technologies is that they have been relatively expensive until recently so that the relatively small size of the market for new pasture cultivars has made the expense difficult for companies to justify together with the fact that the highly heterozygous, cross-pollinating genetic composition of most cool-season grasses adds great complexity to the task (Wang and Brummer 2012). Consequently for forage plants, these technologies have so far primarily been employed for research and development purposes at publically funded institutions. However, the declining cost of these technologies means that their employment more widely is now becoming likely (Hayes et al. 2013; Resende et al. 2014).

Irrespective of breeding methodology, the long-term sustainability of perennial forage crops rests on the improvement of pasture persistence, i.e. maintaining and increasing density over the long term of the sown species, will remain an important objective of pasture plant breeders. Persistence is important for farmers because when optimised, it ensures that pastures need to be resown less frequently, helping to reduce production costs while protecting often fragile landscapes. However, persistence is a phenomenon with multiple components and presupposes tolerance to biotic and abiotic factors which place life-threatening stress on the plant.

This review has considered those abiotic factors, moisture deficit and high temperature, which future climate change scenarios indicate are most likely to constrain the survival and thus persistence of pasture plants in the future. In summary the main recommendations for future research include:

- Increasing the depth and density of grass root systems to strengthen dehydration avoidance;

- Improving understanding of the biochemical and molecular bases of dehydration tolerance and improving techniques to measure this trait;

- Breaking the trade-off between summer dormancy and yield and improving understanding of environmental, biochemical and genetic controls over summer dormancy;

- Identifying non-toxic endophyte strains compatible with and add value to summer-dormant tall fescue cultivars by enhancing persistence and production;

- Enhancing seed production capability of new cultivars;

- Designing agronomic management packages for promoting stable mixtures combining summer-dormant, cool-season perennial grasses and legumes.

The research directions proposed here should improve pasture grass survival in Mediterranean and temperate summerdry environments under the future drier and warmer conditions associated with climate change. However, the need for dispassionate assessment of the potential for these species to become environmental weeds is also necessary for the release of grasses with these superior adaptive traits.

Open Access This article is distributed under the terms of the Creative Commons Attribution 4.0 International License (http:// creativecommons.org/licenses/by/4.0/), which permits use, duplication, adaptation, distribution and reproduction in any medium or format, as long as you give appropriate credit to the original author(s) and the source, provide a link to the Creative Commons license and indicate if changes were made.

\section{References}

Abdelguerfi A, El Hassani TA (2011) Interactions between cereal cropping systems and pastoral areas as the basis for sustainable agriculture development in Mediterranean countries. In: Grassland productivity and Ecosystem services. CAB International., pp 261270. doi: 10.1079/9781845938093.0261

Annicchiarico P, Pecetti L, Bouzerzour H, Kallida R, Khedim A, Porqueddu C, Simoes NM, Volaire F, Lelievre F (2011) Adaptation of contrasting cocksfoot plant types to agricultural environments across the Mediterranean basin. Environ Exp Bot 74:8289. doi:10.1016/j.envexpbot.2011.05.002

Assuero SG, Matthew C, Kemp PD, Latch GCM, Barker DJ, Haslett SJ (2000) Morphological and physiological effects of water deficit and endophyte infection on contrasting tall fescue cultivars. N Z J Agric Res 43(1):49-61. doi:10.1080/00288233.2000.9513408

Assuero SG, Matthew C, Kemp P, Barker DJ, Mazzanti A (2002) Effects of water deficit on Mediterranean and temperate cultivars of tall fescue. Aust J Agric Res 53(1):29-40. doi:10.1071/AR01023

Ball DM, Pederson JF, Lacefield GD (1993) The tall-fescue endophyte. Am Sci 81:370-379

Barth S (2012) Breeding strategies for forage and grass improvement. Ann Bot 110:1261-1262. doi:10.1093/aob/mes219

Bhamidimarri S, Saha MC, Payton ME, Hopkins AA (2012) Phenotyping summer dormancy in tall fescue. Crop Sci 52(1): 413-421. doi:10.2135/cropsci2010.11.0660

Bolger TP, Rivelli AR, Garden DL (2005) Drought resistance of native and introduced perennial grasses of south-eastern Australia. Aust J Agric Res 56:1261-1267. doi:10.1071/AR05075

Bouton JH, Latch GCM, Hill NS, Hoveland C, McCann M, Watson R, Parish J, Hawkins L, Thompson F (2002) Reinfection of tall fescue cvultivars with non-ergot alkaloid producing endophytes. Agronomy Journal 94:567-574. doi:10.2134/agronj2002.5670

Bourke C, Hunt E, Watson R (2009) Fescue-associated oedema of horses grazing on endophyte-inoculated tall fescue grass (Festuca arundinacea) pastures. Australian Veterinary Journal, 87:492-498. doi:10.1111/j.1751-0813.2009.00519x

Briske DD, Fuhlendorf SD, Smeins FE (2003) Vegetation dynamics on rangelands: a critique of the current paradigms. J Appl Ecol 40(4): 601-614. doi:10.1046/j.1365-2664.2003.00837.x

Brookshire ENJ, Weaver T (2015) Long-term decline in grassland productivity driven by increasing dryness. Nat Commun 6:7148. doi: $10.1038 /$ ncomms 8148

Buckner RC, Powell JB, Frakes RV (1979) Historical development. In: Buckner RC BL (ed) Tall fescue Agronomy Monograph 20. ASA, CSSA, and SSSA,, Madison, WI., pp p. 1-8. doi: 10.2134/ agronmonogr20.c1

Butler TJ, Islam MA, Muir JP (2008) Establishing cool-season perennial grasses into former annual grass pastures in the Southern Great Plains. Forage Grazinglands. doi:10.1094/FG-2008-0911-01-RS 
Butler TJ, Stein JD, Interrante SM, Malinowski DP (2011) Novel approaches to establishing alfalfa-tall fescue pastures in the Southern Great Plains. Forage Grazinglands. doi:10.1094/FG-2011-0725-01RS

Carr GW, Yugovic JV, Robinson KE (1992) Environmental weed invasions in Victoria. Conservation and management implications. Department of Conservation and Environment, Melbourne

Cashmore AB (1934) A comparative study of Lolium perenne and Phalaris tuberosa at varying stages of growth. Bulletin of the Council for Scientific and Industrial Research of Australia

Charles S, Fu G (2012) Indian Ocean Climate Initiative Stage 3 (IOCI3) - downscaled climate projections for Western Australia. v2

Christensen MJ, Leuchtmann A, Rowan DD, Tapper BA (1993) Taxonomy of Acremonium endophytes of tall fescue (Festuca arundinacea), meadow fescue (F. pratensis), and perennial ryegrass (Lolium perenne). Mycol Res 97:1083-1092. doi:10.1016/S09537562(09)80509-1

Ciais P, Reichstein M, Viovy N, Granier A, Ogee J, Allard V, Aubinet M, Buchmann N, Bernhofer C, Carrara A, Chevallier F, De Noblet N, Friend AD, Friedlingstein P, Grunwald T, Heinesch B, Keronen P, Knohl A, Krinner G, Loustau D, Manca G, Matteucci G, Miglietta F, Ourcival JM, Papale D, Pilegaard K, Rambal S, Seufert G, Soussana JF, Sanz MJ, Schulze ED, Vesala T, Valentini R (2005) Europe-wide reduction in primary productivity caused by the heat and drought in 2003. Nature 437:529-533. doi:10.1038/nature03972

CIHEAM (2009) Mediterra - Repenser le développement rural en Méditerranée Presses de Sciences Po, Paris

Clement SL, Elberson LR, Youssef NN, Davitt CM, Doss RP (2000) Incidence and diversity of Neotyphodium fungal endophytes in tall fescue from Morocco, Tunisia, and Sardinia. Crop Sci 41:570-576. doi:10.2135/cropsci2001.412570x

Clement SL, Elberson LR, Youssef NN, Davitt CM, Doss RP (2001) Incidence and diversity of Neotyphodium fungal endophytes in tall fescue from Morocco, Tunisia, and Sardinia. Crop Sci 41:570-576. doi:10.2135/cropsci2001.412570x

Cooper JP (1963) Species and population differences in climatic response. In: Evans LT (ed) Environmental control of plant growth. Academic, New York, pp 381-403. doi:10.1016/b978-0-12244350-3.50025-2

Craine JM et al (2013) Global diversity of drought tolerance and grassland climate-change resilience. Nat Clim Chang 3:63-67. doi:10. 1038 /nclimate 1634

Craven KD, Clay K, Schardl CL (2005) Systematics and morphology. In: Tall Fescue on-Line Monograph. Oregon State University Extension Service and the University of Tennessee Agricultural Experiment Station

Craven KD, Clay K, Schardl CL (2009) Systematics and morphology. . Oregon State University Extension Service and the University of Tennessee Agricultural Experiment Station,. available at: http:// forages.oregonstate.edu/tallfescuemonograph/toc Accessed (accessed 8 Oct 2015)

Culvenor RA, Boschma SP (2005) Evaluation of phalaris (Phalaris aquatica L.) germplasm for persistence under grazing on the North-West Slopes, New South Wales. Aust J Agric Res 56(7): 731-741. doi:10.1071/AR04300

Culvenor RA, Clark SG, Harris CA, Hayes RC, Li GD, Nie ZN, Norton MR, Partington DL (2016) Field evaluation of cocksfoot, tall fescue and phalaris for dry marginal environments of south-eastern Australia. 2. Persistence. J Agron Crop Sci. doi:10.1111/jac.12141

Dear BS, Virgona JM, Sandral GA, Swan AD, Orchard BA (2007) Lucerne, phalaris, and wallaby grass in short-term pasture phases in two eastern Australian wheatbelt environments. 1. Importance of initial perennial density on their persistence and recruitment, and on the presence of weeds. Aust J Agric Res 58(2):113-121. doi:10. 1071/ar05323
Delgado C, Rosegrant M, Steinfeld H, Ehui S, Courbois C (1999) Livestock to 2020: the next food revolution. IFPRI, Washington

Demel RA, Dorrepaal E, Ebskamp MJM, Smeekens JCM, de Kriujff B (1998) Fructans interact strongly with model membranes. Biochim Biophys Acta 1375:36-42. doi:10.1016/S0005-2736(98)00138-2

FAO (2009) The state of food and agriculture. Livestock in the balance. Rome, Italy

Fernández-Alés R, Laffarga JM, Ortega F (1993) Strategies in Mediterranean grassland annuals in relation to stress and disturbance. J Veg Sci 4:313-322. doi:10.2307/3235589

Flavel RJ, Guppy CN, Watt M, Young IM (2012) Non-Destructive quantification of cereal roots over time in soil using high resolution X-ray tomography. J Exp Bot 63:2503-2511. doi:10.1093/jxb/err421

Flower DJ, Ludlow MM (1986) Contribution of osmotic adjustment to the dehydration tolerance of water-stressed pigeon pea (Cajanus cajan (L.) Millsp.) leaves. Plant Cell Environ 9:33-40. doi:10. 1111/j.1365-3040.1986.tb01720.x

Flower DJ, Ludlow MM (1987) Variation among accessions of pigeonpea (Cajanus cajan) in osmotic adjustment and dehydration tolerance of leaves. Field Crop Res 17:229-243

Garwood EA, Sinclair J (1979) Use of water by six grass species. 2. Root distribution and use of soil water. J Agric Sci Camb 93:25-35. doi: 10.1017/S0021859600086081

Gaujour E, Amiaud B, Mignolet C, Plantureux S (2012) Factors and processes affecting plant biodiversity in permanent grasslands. A review. Agron Sustain Dev 32:133-160. doi:10.1007/s13593-0110015-3

Giannakopoulos C, Le Sager P, Bindi M, Moriondo M, Kostopoulou E, Goodess CM (2009) Climatic changes and associated impacts in the Mediterranean resulting from a 2 degrees $\mathrm{C}$ global warming. Glob Planet Chang 68(3):209-224. doi:10.1016/j.gloplacha.2009.06.001

Gillen RL, Berg WA (2005) Response of perennial cool-season grasses to clipping in the Southern Plains. Agron J 97:125-130. doi:10.2134/ agronj2005.0125

Hackney B, Dear BS, Hayes RC (2006) Summer dormant temperate grasses are productive and persistent in the medium - low rainfall cropping region of New South Wales. Paper presented at the Proceedings of 13th Conference of the Australian Society of Agronomy, Perth

Hardy JP, Anderson VJ, Gardner JS (1995) Stomatal characteristics, conductance ratios, and drought-induced leaf modifications of semiarid grassland species. Am J Bot 82 (1):1-7

Harris CA, Boschma SP, Moore G (2009) Developing a more productive, persistent panic grass cultivar. Trop Grasslands 43:269-270

Hayes RC, Dear BS, Li GD, Virgona JM, Conyers MK, Hackney BF, Tidd J (2010) Perennial pastures for recharge control in temperate drought-prone environments. Part 1: productivity, persistence and herbage quality of key species. N Z J Agric Res 53:283-302. doi: 10.1080/00288233.2010.515937

Hayes JH, Cogan NO, Pembleton LW, Goddard ME, Wang J, Spangenberg GC, Forster JW (2013) Prospects for genomic selection in forage plant species. Plant Breed 132:133-143. doi:10.1111/ pbr. 12037

Hill N, Stringer W, Rottinghaus G, Belesky D, Parrott W, Pope D (1990) Growth, morphological and chemical component responses of tall fescue to Acremonium coenophiala. Crop Sci 30:156-161. doi:10. 2135/cropsci1990.0011183X003000010034x

Hoerling M, Eischeid J, Perlwitz J, Quan XW, Zhang T, Pegion P (2012) On the increased frequency of Mediterranean drought. J Clim 25(6): 2146-2161. doi:10.1175/jcli-d-11-00296.1

Hoover DL, Knapp AK, Smith MD (2014) Resistance and resilience of a grassland ecosystem to climate extremes. Ecology 95:2646-2656. doi:10.1890/13-2186.1

Hossain IE, F.M., Horn GW, Krenzer EG, Jr (2004) Wheat production and management practices used by Oklahoma grain and livestock producers., vol Bulletin B-818. Oklahoma State University 
Agricultural Experiment Station,, Oklahoma State University, Stillwater, Oklahoma

Hoveland CS (2009) Origin and history. In Tall Fescue On-line Monograph Oregon State University Extension Service, The University of Tennessee Agricultural Experiment Station, and University of Arkansas, College of Agricultural, Food and Life Sciences

Hunt MG, Newman JA (2005) Reduced herbivore resistance from a novel grass-endophyte association. J Appl Ecol 42:762-769. doi: 10.1111/j.1365-2664.2005.01061.x

Hunt KL, Sleper DA (1981) Fertility of hybrids between two geographic races of tall fescue. Crop Sci 21:400-404. doi:10.2135/cropsci1981. 0011183X002100030012x

IPCC (2014) Intergovernmental Panel on Climate Change 5th Assessment Report (AR5)- Climate Change 2014: Impacts, Adaptation, and Vulnerability

Johnston WH (1996) The place of C4 grasses in temperate pastures in Australia. N Z J Agric Res 39(4):527-540

Kallida R, Zhouri L, Volaire F, Guerin A, Julier B, Shaimi N, Fakiri M, Barre P (2016) Combining drought survival via summer dormancy and annual biomass productivity in Dactylis glomerata L. Front Plant Sci 7:82. doi:10.3389/fpls.2016.00082

Karl TR, Melillo JM, Peterson TC (2009) Global climate change impacts in the United States.

Kirkegaard JA, Hunt JR (2010) Increasing productivity by matching farming system management and genotype in water-limited environments. J Exp Bot. doi:10.1093/jxb/erq245

Knight R (1965) The relation between yield and reproductive phase in cocksfoot (Dactylis glomerata L.) in a winter rainfall environment. Aust J Agric Res 16:505-515. doi:10.1071/AR9650505

Kooyers NJ (2015) The evolution of drought escape and avoidance in natural herbaceous populations. Plant Sci 234:155-162. doi:10. 1016/j.plantsci.2015.02.012

Kramer PJ (1980) Drought stress and the origin of adaptations. In: Turner NC, Kramer PJ (eds) Adaptation of plants to water and high temperature stress. Wiley, New York, pp 7-20

Larkin PJ, Newell MT, Hayes RC, Aktar J, Norton MR, Moroni SJ, Wade LJ (2014) Progress in developing perennial wheats for grain and grazing. Crop Pasture Sci 65:1147-1164. doi:10.1071/CP13330

Lehner B, Doll P, Alcamo J, Henrichs T, Kaspar F (2006) Estimating the impact of global change on flood and drought risks in Europe: a continental, integrated analysis. Clim Chang 75:273-299. doi:10. 1007/s10584-006-6338-4

Lelievre F, Volaire F (2009) Current and potential development of perennial grasses in rainfed Mediterranean farming systems. Crop Sci 49(6):2371-2378. doi:10.2135/cropsci2009.06.0324

Lelièvre F, Seddaiu G, Ledda L, Porqueddu C, Volaire F (2011) Water use efficiency and drought survival in Mediterranean perennial forage grasses. Field Crop Res 121(3):333-342. doi:10.1016/j.fcr.2010.12. 023

Lens F, Tixier A, Cochard H, Sperry JS, Jansen S, Herbette S (2013) Embolism resistance as a key mechanism to understand adaptive plant strategies. Curr Opin Plant Biol 16:287-292. doi:10.1016/j. pbi.2013.02.005

Leuchtmann A, Bacon CW, Schardl CL, White JF, Tadych M (2014) Nomenclatural realignment of Neotyphodium species with genus Epichloë. Mycologia 106:202-215. doi:10.3852/13-251

Levitt J (ed) (1980) Responses of plants to environmental stresses, vol 2, 2nd edn. Academic, New York

Lewis GC (2000) Neotyphodium endophytes: Incidence, diversity, and hosts in Europe. In: Paul VH DP (ed) Proceedings of the 4th International Neotyphodium/Grass Interactions Symposium Soest, Germany, 27-29 September 2000. pp 123-130

Lewis GC, Ravel C, Naffaa W, Astier C, Charmet G (1997) Occurrence of Acremonium endophytes in wild populations of Lolium spp. in European countries and a relationship between level of infection and climate in France. Ann Appl Biol 130:227-238. doi:10.1111/j.17447348.1997.tb06828.x

Malinowski DP, Belesky DP (2000) Adaptations of endophyte-infected cool-season grasses to environmental stresses: mechanisms of drought and mineral stress tolerance. Crop Sci 40:923-940. doi: 10.2135/cropsci2000.404923x

Malinowski DP, Hopkins AA, Pinchak WE, Sij JW, Ansley RJ (2003) Productivity and survival of defoliated wheatgrasses in the Rolling Plains of Texas. Agron J 95:614-626. doi:10.2134/agronj2003.0614

Malinowski DP, Zuo H, Belesky DP, Alloush GA (2004) Evidence for copper binding by extracellular root exudates of tall fescue but not perennial ryegrass infected with Neotyphodium spp. endophytes. Plant Soil 267:1-12. doi:10.1007/s11104-005-2575-y

Malinowski DP, Zuo H, Kramp BA, Muir JP, Pinchak WE (2005) Obligatory summer-dormant cool-season perennial grasses for semiarid environments of the Southern Great Plains. Agron J 97:147154. doi:10.2134/agronj2005.0147

Malinowski D, Belesky DP, Kramp BA, Ruckle J, Kigel J, Pinchak WE (2008) A method to differentiate summer-dormant from summeractive tall fescue and orchardgrass accessions at germination stage. Aust J Agric Res 59(12):1092-1102. doi:10.1071/AR08084

Malinowski DP, Kigel J, Pinchak WE (2009) Water deficit, heat tolerance, and persistence of summer-dormant grasses in the U.S. Southern Plains. Crop Sci 49(6):2363-2370. doi:10.2135/ cropsci2009.06.0316

Malinowski DP, Butler TJ, Belesky DP (2011) Competitive ability of tall fescue against alfalfa as a function of summer dormancy, endophyte infection, and soil moisture availability. Crop Sci 51(3):1282-1290. doi:10.2135/cropsci2010.08.0456

McDowell N, Pockman WT, Allen CD, Breshears DD, Cobb N, Kolb T, Plaut J, Sperry J, West A, Williams DG, Yepez EA (2008) Mechanisms of plant survival and mortality during drought: why do some plants survive while others succumb to drought? New Phytol 178(4):719-739. doi:10.1111/j.1469-8137.2008.02436.x

McWilliam JR (1968) The nature of the perennial response in Mediterranean grasses. 2. Senescence, summer dormancy, and survival in Phalaris. Aust J Agric Res 19:397-409. doi:10.1071/ AR9680397

McWilliam JR, Kramer PJ (1968) The nature of the perennial response in Mediterranean grasses. 1. Water relations and summer survival in Phalaris. Aust J Agric Res 19:381-395. doi:10.1071/AR9680381

Miller JE (2000) Flecha, syn. Grasslands Flecha. Plant Varieties J 13:3132

Minson DJ (1990) Forage in ruminant nutrition. Animal Feeding and Nutrition. Academic, San Diego

Minson DJ, McLeod MN (1970) The digestibility of temperate and tropical grasses. In: Proceedings 1lth Int. Grassland Congr., St. Lucia, Queensland, Australia, pp. 719

Motha RP, Baier W (2005) Impacts of present and future climate change and climate variability on agriculture in the temperate regions: North America. Clim Chang 70:137-164. doi:10.1007/s10584-005-5940-1

Naveh Z (1960) Mediterranean grasslands in California and Israel. J Rangeland Manag 13:302-306. doi:10.2307/3894785

Nie ZN, Miller S, Moore GA, Hackney BF, Boschma SP, Reed KFM, Mitchell M, Albertsen TO, Clark SG, Craig AD, Kearney G, Li GD, Dear BS (2008) Field evaluation of perennial grasses and herbs in southern Australia. 2. Persistence, root characteristics and summer activity. Aust J Exp Agric 48:424 435. doi:10.1071/EA07136

Nielsen-Gammon JW (2011) The changing climate of Texas. In: J. Schmandt JC, North GR (ed) The impact of global warming on Texas. 2nd edn. University of Texas Press, Austin

Nordblom TL, Hutchings TR, Hayes RC, Li GD (2015) A framework for modelling whole-farm financial risk. Paper presented at the 59th Australian Agricultural and Resource Economics Society Annual Conference., Rotorua, New Zealand, 10-13 February, 2015 
Norton MR (2007) The role of summer dormancy in improving survival of temperate perennial pasture grasses in drought-prone environments. $\mathrm{PhD}$, University of Queensland, Brisbane, Australia

Norton MR, Koetz EA, Stewart G (2001) Perennial grass evaluation for southern mixed farming systems. Paper presented at the Proc. 16th Ann. Conf. Grasslands Soc. of NSW

Norton MR, Lelievre F, Volaire F (2006a) Summer dormancy in Dactylis glomerata L., the influence of season of sowing and a simulated mid-summer storm on two contrasting cultivars. Aust J Agric Res 57(5):565-575. doi:10.1071/AR05237

Norton MR, Volaire F, Lelievre F (2006b) Summer dormancy in Festuca arundinacea Schreb., the influence of season of sowing and a simulated mid-summer storm on two contrasting cultivars. Aust J Agric Res 57:1267-1277. doi:10.1071/AR06082

Norton MR, Lelievre F, Fukai S, Volaire F (2008) Measurement of summer dormancy in temperate perennial pasture grasses. Aust J Agric Res 59(6):498-509. doi:10.1071/AR07343

Norton MR, Lelievre F, Volaire F (2012) Summer dormancy in Phalaris aquatica L., the influence of season of sowing and summer moisture regime on two contrasting cultivars. J Agron Crop Sci 198(1):1-13. doi:10.1111/j.1439-037X.2011.00482.x

Norton MR, Lelièvre F, Volaire F (2014) Measuring dehydration tolerance in pasture grasses to improve drought survival. Crop Pasture Sci 65(8):828-840. doi:10.1071/CP14054

Ofir M (1975) The morphogenesis of regeneration buds in Hordeum bulbosum L. - a perennial grass. Ann Bot 39(160):213-217

Ofir M (1976) Interaction of gibberellin with photoinduction in the initiation of the dormant phase in vernalized Hordeum bulbosum L. Aust J Plant Physiol 3(6):827-832. doi:10.1071/PP9760827

Ofir M (1981) Effects of induction level on morphogenetic aspects of onset of summer dormancy and flowering in Hordeum bulbosum L. Israel J Bot 30(4):173-180

Ofir M (1986) Seasonal changes in the response to temperature of summer-dormant Poa bulbosa L. bulbs. Ann Bot 58(1):81-89

Ofir M, Dorenfield Y (1992) Induction of summer-dormancy in Poa bulbosa L. under natural environment and subsequent controlled photo-thermal conditions. Israel J Bot 41(4-6):265-277

Ofir M, Kerem D (1982) The effects of temperature and photoperiod on the onset of summer dormancy in Poa bulbosa L. Ann Bot 50(2): 259-264

Ofir M, Kigel J (1998) Abscisic acid involvement in the induction of summer-dormancy in Poa bulbosa, a grass geophyte. Physiol Plant 102(2):163-170. doi:10.1034/j.1399-3054.1998.1020202.x

Ofir M, Kigel J (1999) Photothermal control of the imposition of summer dormancy in Poa bulbosa, a perennial grass geophyte. Physiol Plant 105(4):633-647. doi:10.1034/j.1399-3054.1999.105406.x

Ofir M, Kigel J (2003) Variation in onset of summer dormancy and flowering capacity along an aridity gradient in Poa bulbosa L., a geophytic perennial grass. Ann Bot 91(3):391-400. doi:10.1093/ $\mathrm{aob} / \operatorname{mcg} 026$

Ofir M, Kigel J (2006) Opposite effects of daylength and temperature on flowering and summer dormancy of Poa bulbosa. Ann Bot 97 (4). doi: $10.1093 / \mathrm{aob} / \mathrm{mcl} 021$

Ofir M, Koller D (1972) A kinetic analysis of the relationships between flowering and initiation of the dormant state in Hordeum bulbosum L. - a perennial grass. Israel J Bot 21(1):21-34

Ofir M, Koller D (1974) Relationship between thermoinduction and photoinduction of flowering and dormancy in Hordeum bulbosum L., a perennial grass. Aust J Plant Physiol 1(2):259-270. doi:10.1071/ PP9740259

Ofir M, Koller D, Negbi M (1967) Studies on the physiology of regeneration buds of Hordeum bulbosum. Bot Gaz 128:25-34. doi:10. $1086 / 336378$

Oliver MJ, Cushman JC, Koster KL (2010) Dehydration Tolerance in Plants. In: Plant Stress Tolerance. Methods in Molecular Biology, vol 639. Humana Press, (Clifton, N.J.) pp 3-24. doi:10.1007/978-160761-702-0 1

Oram RN (1984) Inheritance of conditional dormancy in over-summering buds of Phalaris aquatica L. Euphytica 33:313-319

Oram RN (1990) Register of Australian Herbage Plant Cultivars, 3rd edn. CSIRO, East Melbourne

Palta JA, Chen X, Milroy SP, Rebetzke GJ, Dreccer FM, Watt M (2011) Large root systems: are they useful in adapting wheat to dry environments? Funct Plant Biol 38:347-354. doi:10.1071/FP11031

Passioura J (2006) Increasing crop productivity when water is scarcefrom breeding to field management. Agric Water Manag 80:176196. doi:10.1016/j.agwat.2005.07.012

Pau S, Edwards EJ, Still CJ (2013) Improving our understanding of environmental controls on the distribution of $\mathrm{C} 3$ and $\mathrm{C} 4$ grasses. Glob Chang Biol 19:184-196. doi:10.1111/gcb.12037

Pecetti L, Romani M, Carroni AM, Annicchiarico P, Piano E (2007) The effect of endophyte infection on persistence of tall fescue (Festuca arundinacea Schreb.) populations in two climatically contrasting Italian locations. Aust J Agric Res 58(9):893-899. doi:10.1071/ $\operatorname{ar} 06423$

Pecetti L, Annicchiarico P, Porqueddu C, Khedim A, Abdelguerfi A (2009) Fitting germplasm types of tall fescue and orchardgrass to different cropping environments of the Mediterranean region. Crop Sci 49(6):2393-2399. doi:10.2135/cropsci2009.06.0333

Piano E, Bertoli FB, Romani M (2005) Specificity of host-endophyte association in tall fescue populations from Sardinia, Italy. Crop Sci 45:1456-1463. doi:10.2135/cropsci2004.0287

Pinchak WE, Worrall WD, Caldwell SP, Hunt LJ, Worrall NJ, Conoly M (1996) Interrelationships of forage and steer growth dynamics on wheat pasture. J Range Manag 49:126-130. doi:10.2307/4002681

Poirier M, Durand JL, Volaire F (2012) Persistence and production of perennial grasses under water deficits and extreme temperatures: importance of intraspecific vs. interspecific variability. Glob Chang Biol 18(12):3632-3646. doi:10.1111/j.1365-2486.2012. 02800.x

Rahnama A, Munns R, Poustini K, Watt M (2011) A screening method to identify genetic variation in root growth response to a salinity gradient. J Exp Bot 62:69-77. doi:10.1093/jxb/erq359

Reed KFM, Nie ZN, Miller S, Hackney BF, Boschma SP, Mitchell ML, Albertsen TO, Moore GA, Clark SG, Craig AD, Kearney G, Li GD, Dear BS (2008) Field evaluation of perennial grasses and herbs in Southern Australia. 1. Establishment and herbage production. Aust J Exp Agric 48(4):409-423. doi:10.1071/EA07135

Reich PB (2014) The world-wide 'fast-slow' plant economics spectrum: a traits manifesto. J Ecol 102:275-301. doi:10.1111/1365-2745.12211

Resende RMS, Casler MD, Resende MDV (2014) Genomic selection in forage breeding: accuracy and methods. Crop Sci 54:143-156. doi: 10.2135/cropsci2013.05.0353

Reuter RR, Horn GW (2002) Cool-season perennial grasses as complementary forages to winter wheat pasture. Prof Anim Sci 18:44-51

Ritchie JT (1983) Efficient water use in crop production: discussion on the generality of relations between biomass production and evapotranspiration. Limitations to efficient water use in crop production. American Society of Agronomy, Wisconsin

Saikkonen K, Wäli P, Helander M, Faeth SH (2004) Evolution of endophyte-plant symbioses. Trends Plant Sci 9:275-280. doi:10. 1016/j.tplants.2004.04.005

Schar C, Jendritzky G (2004) Climate change: hot news from summer 2003. Nature 432:559-560. doi:10.1038/432559a

Shaimi N, Kallida R, Volaire F, Al Faiz C (2009) Summer dormancy in orchardgrass: evaluation and characterization through ecophysiological and genetic studies. Crop Sci 49(6):2353-2358. doi:10. 2135/cropsci2009.06.0325

Simpson WR, Mace WJ (2012) Novel associations between epichloid endophytes and grasses: possibilities and outcomes. Epichloae, endophytes of cool season grasses: implications, utilization and 
biology. The Samuel Roberts Noble Foundation,, Ardmore Oklahoma, USA

Sleper DA (1985) Breeding tall fescue. In: Janick J (ed) Plant Breeding Reviews, vol Vol. 3. AVI Publishing Company Inc, Westport, CT, USA, pp 313-342. doi: 10.1002/9781118061008.ch8

Sprague SJ, Watt M, Kirkegaard JA, Howlett BJ (2007) Pathways of infection of Brassica napus roots by Leptosphaeria maculans. New Phytol 176:211-222. doi:10.1111/j.1469-8137.2007.02156.x

Stein JD, Butler TJ, Malinowski D (2009) Alfalfa-tall fescue row orientations/compatibility comparisons on establishment and persistence under livestock grazing. Paper presented at the In: Proceedings American Forage Grassland Conference, Grand Rapids, MI, 21-23 June 2009

Still CJ, Berry JA, Collatz GJ, DeFries RS (2003) Global distribution of $\mathrm{C} 3$ and $\mathrm{C} 4$ vegetation: carbon cycle implications. Glob Biogeochem Cycles 17:1006

Taher Sraïri M (2011) Le développement de l'élevage au Maroc: succès relatifs et dépendance alimentaire. Courrier de l'Environnement de l'INRA 60:91-101

Teuber LR, Taggard KL, Gibbs LK, Orloff SE, Mueller SC, Frate CA, Putnam DH, Volenec JJ (1998) Check cultivars, Locations, and Management, of fall dormancy evaluation. . Paper presented at the Proc. 36th N Am Alfalfa Imp Conf, Bozeman, MT

Timbal B, Arblaster JM, Power S (2006) Attribution of the late-twentiethcentury rainfall decline in Southwest Australia. J Clim 19:20462062. doi:10.1175/JCLI3817.1

Tubiello FN, Soussana JF, Howden SM (2007) Crop and pasture response to climate change. Proc Natl Acad Sci U S A 104:19686-19690. doi: 10.1073/pnas.0701728104

Turner NC (1986) Adaptation to water deficits: a changing perspective. Aust J Plant Physiol 13:175-190. doi:10.1071/PP9860175

Turner NC (1997) Further progress in crop water relations. Advances in Agronomy 58. doi: 10.1016/S0065-2113(08)60258-8

Turner NC (2003) Drought resistance: a comparison of two research frameworks. In: Management of agricultural drought: agronomic and genetic options. Science Publishers Inc., Enfield, USA

Turner NC, Li FM, Xiong YC, Siddique KHM (2011) Agricultural ecosystem management in dry areas: challenges and solutions. Plant Soil 347:1-6. doi:10.1007/s11104-011-0949-x

USDA-NISIC (2013) Invasive species list

USDA-NRCS (2013) Introduced, invasive, and noxious plants

Vaughn KJ, Biel C, Clary JJ, de Herralde F, Aranda X, Evans RY, Young TP, Savé R (2011) California perennial grasses are physiologically distinct from both Mediterranean annual and perennial grasses. Plant Soil 345:37-46. doi:10.1007/s11104-011-0757-3

Verdon-Kidd DC, Kiem AS (2009) Nature and causes of protracted droughts in southeast Australia: Comparison between the Federation, WWII, and Big Dry droughts. Geophys Res Lett 36 (L22707). doi: 10.1029/2009g1041067

Verslues PE, Agarwal M, Katiyar-Agarwal S, Zhu JH, Zhu JK (2006) Methods and concepts in quantifying resistance to drought, salt and freezing, abiotic stresses that affect plant water status. Plant J 45(4): $523-539$

Volaire F (2002) Drought survival, summer dormancy and dehydrin accumulation in contrasting cultivars of Dactylis glomerata. Physiol Plant 116:42-51. doi:10.1034/j.1399-3054.2002.1160106.x
Volaire F (2003) Seedling survival under drought differs between an annual (Hordeum vulgare L.) and a perennial grass (Dactylis glomerata L.). New Phytol 160:501-510. doi:10.1046/j.14698137.2003.00906.x

Volaire F, Lelievre F (1997) Production, persistence, and water-soluble carbohydrate accumulation in 21 contrasting populations of Dactylis glomerata L. subjected to severe drought in the south of France. Aust J Agric Res 48:933-944. doi:10.1071/A97004

Volaire F, Lelievre F (2001) Drought survival in Dactylis glomerata and Festuca arundinacea under similar rooting conditions in tubes. Plant Soil 229:225-234. doi:10.1023/A:1004835116453

Volaire F, Norton M (2006) Summer dormancy in perennial temperate grasses. Ann Bot 98:927-933. doi:10.1093/aob/mcl195

Volaire F, Thomas H, Lelievre F (1998) Survival and recovery of perennial forage grasses under prolonged Mediterranean drought: growth, death, water relations and solute content in herbage and stubble. New Phytol 140:439-449. doi:10.1046/j.1469-8137.1998.00288.x

Volaire F, Conejero G, Lelievre F (2001) Drought survival and dehydration tolerance in Dactylis glomerata and Poa bulbosa. Aust J Plant Physiol 28:743-754. doi:10.1071/pp00162

Volaire F, Norton MR, Norton GM, Lelievre F (2005) Seasonal patterns of growth, dehydrins and water-soluble carbohydrates in genotypes of Dactylis glomerata varying in summer dormancy. Ann Bot 95: 981-990. doi:10.1093/aob/mci102

Volaire F, Barkaoui K, Norton M (2014) Designing resilient and sustainable grasslands for a drier future: adaptive strategies, functional traits and biotic interactions. Eur J Agron 52:81-89. doi:10.1016/j.eja. 2013.10.002

Walter A, Studer B, Koelliker R (2012) Advanced phenotyping offers opportunities for improved breeding of forage and turf species. Annals of Botany 110. doi: 10.1093/aob/mcs026

Wang Z-Y, Brummer EC (2012) Is genetic engineering ever going to take off in forage, turf and bioenergy crop breeding? Ann Bot 110:13171325. doi:10.1093/aob/mes027

Wang J, Wang E, Luo Q, Kirby M (2009) Modelling the sensitivity of wheat growth and water balance to climate change in Southeast Australia. Clim Chang 96:79-96. doi:10.1007/s10584-009-9599-x

Wasson AP, Richards RA, Chatrath R, Misra SC, Sai Prasad SV, Rebetzke GJ, Kirkegaard JA, Christopher J, Watt M (2012) Traits and selection strategies to improve root systems and water uptake in water-limited wheat crops. J Exp Bot 63:3485-3498. doi:10.1093/ jxb/ers 111

Watt M, McCully ME, Kirkegaard JA (2003) Soil strength and rate of root elongation alter the accumulation of Pseudomonas spp. and other bacteria in the rhizosphere of wheat. Funct Plant Biol 30: 482-491. doi:10.1071/FP03045

West CP, Norton MR, Volaire F, Hopkins AA, Malinowski DP (2009) First international workshop on summer dormancy in grasses: coping with climate change, Samuel Roberts Noble Foundation, Ardmore, OK, USA, 6-8 April 2009. Crop Sci 49 (6):2325-2411. doi:10.2135/cropsci2009.06.0313

Young CA, Hume DE, McCulley RL (2015) Fungal endophytes of tall fescue and perennial ryegrass: pasture friend or foe? J Anim Sci 91(5):2379-2394. doi:10.2527/jas.2012-5951 